\title{
MULTIPLIER EFFECTS OF LATVIAN RURAL DEVELOPMENT PROGRAMME 2007-2013
}

\author{
Elita Benga, Juris Hāzners, Zaiga Miķelsone \\ Institute of Agricultural Resources and Economics, Research Center of Economics, Division of Rural \\ Development Evaluation. Address: Struktoru street 14, Riga, Latvia, LV-1039.
}

\begin{abstract}
The core question to be answered in periodic evaluations of EU Member States Rural Development Programme (RDP) specific policy interventions is whether the stated objectives are accomplished by particular intervention (support or "treatment” provided to programme participants). Programme effects should normally be expressed in "net" terms, which means after subtracting the effects that cannot be attributed to the intervention, and by taking into account indirect effects (deadweight, leverage, displacement, substitution and multipliers). The level of the estimation of indirect effects (micro or macro level) depends on the size of the interventions and country specific issues. In the ex-post evaluation of the Latvian Rural Development programme 2007-2013, deadweight effects, leverage effects and multipliers are estimated at the individual measure (micro) level, while substitution and displacement effects are aggregated over the sets of measures. Multiplier effect is a secondary effect resulting from increased income and consumption generated by the public intervention. Multiplier effects are cumulative and take into account the fact that a part of the income generated is spent again and generates other income, and so on in several successive cycles. In each cycle, the multiplier effect diminishes due to purchases outside the territory. The existing study provides an assessment of the multiplier coefficients (multipliers) for the economic growth in terms of Gross Value Added and for the employment creation in terms of Annual Working Units. The research results show that total estimated programme secondary cumulative impacts on economic growth and employment over the entire economy are significant and positive.
\end{abstract}

Keywords: policy evaluation, input-output analysis, secondary cumulative impact, multipliers, multiplier effects.

\section{INTRODUCTION}

The core question to be answered in periodic evaluations of EU Member States Rural Development Programme (RDP) specific policy interventions is whether the stated objectives are accomplished by particular intervention (support or „treatment” provided to programme participants). Programme effects should normally be expressed in "net" terms, which means after subtracting the effects that cannot be attributed to the intervention, and by taking into account indirect effects (deadweight, leverage, displacement, substitution and multipliers). The level of the estimation of indirect effects (micro or macro level) depends on the size of the interventions and country specific issues. In the ex-post evaluation of the Latvian Rural Development programme 20072013, deadweight effects, leverage effects and multipliers are estimated at the individual measure (micro) level, while substitution and displacement effects are aggregated over the sets of measures. Multiplier effect is a secondary effect resulting from increased income and consumption generated by the public intervention. Multiplier effects are cumulative and take into account the fact that a part of the income generated is spent again and generates other income, and so on in several successive cycles. In each cycle, the multiplier effect diminishes due to purchases outside the territory. Correctly estimating programme multiplier effects is a rather difficult issue. The possible methodological approaches proposed in the evaluation guidelines by European Evaluation Network for Rural Development [1] are the following: regional Social Accounting Matrix (SAM), regional Input - Output models (Input-Output tables) or general propensity score based models.

The use of Input-Output (I/O) tables in empirical analyses has notably increased recently. Input-Output (I/O) multipliers and multiplier effects can be used to assess the national economic impacts from an activity, such as investments under the framework of Rural Development Programmes. Multipliers are derived from a national $\mathrm{I} / \mathrm{O}$ table or matrix which is a representation of national or regional economic accounting that records the way industries both trade with one another and produce for consumption and investments. The flows of products and services are registered, simultaneously by origin and by destination. The use of $\mathrm{I} / \mathrm{O}$ multipliers for impact assessment of policy interventions rests on the fact that the direct effects of the investments in a specific sector of the economy (agriculture, forestry, food processing or public services) are followed by

ISSN 1691-5402

(C) Rezekne Academy of Technologies, Rezekne 2017 http://dx.doi.org/10.17770/etr2017vol1.2527 
indirect and induced effects. These two types of effects are observed respectively because purchasing links with other industries in the national level exist and employees who work in the value chain spend their incomes on domestic goods and services.

\section{MATERIALS AND METHODS}

Input-output (I/O) analysis has been developed by Leontief who has applied the I/O model on the U.S. economy [3] - [5]. Two main I/O techniques are impact analysis and the projection (or imputation) of primary inputs [9], [6]. Impact analysis, which is the most traditional I/O technique, studies the impact of a changing final demand on the production of economic sectors. The second technique concerns the projection of primary inputs on final demand. Although traditionally, only the inputs of labour and capital were analysed, later other types of inputs were also taken into account. Both I/O techniques mentioned require the calculation of so-called Leontief multipliers. The impact estimates derived from I/O analysis represent activity within a single year. Thus, the economic impact assessment is mostly used as a one shot assessment. The I/O multipliers and multiplier effects are commonly assumed stable for up to six years after the initial calculation of the $\mathrm{I} / \mathrm{O}$ table. If the data are available enabling the initialization of the impact assessment each year, the different scenarios can be analyzed. However, usually $\mathrm{I} / \mathrm{O}$ tables are available with time gaps 36 months after the year selected for the analysis. The method has further limitations. The assessment pertains only to economic impacts and it does not address the environmental, social or cultural issues. The errors in terms of estimation of the direct impacts are added up and contribute to the uncertainty in the final results. Even though it cannot be clearly measured, presenting the results in terms of ranges of values (rough confidence intervals) rather than a single figure can help to underline the inherent uncertainty of an economic impact analysis. A sensitivity analysis can also help. It might also be interesting to first present the direct effects in terms of spending or change in final demand (supposedly highlighted in the simulation model) and the multipliers; to then show the broader impact (including the indirect and induced effects) while explaining the differences and underlying uncertainties with respect to each step of the method. This will help shed light on the importance of broadening the perspective, away from considering the simple direct impacts of one measure. At the same time, it will provide a good picture of the assessment.

Basic principles of Input-Output methodology and calculation of Input-Output multipliers

The I/O methodology has been applied in the analysis of various industry sectors. Nevertheless, predominantly research focuses on tourism and related economy sectors. In Scotland, initially suggested approach of Stynes [11] was further developed by Wilson [13]. In the Scottish Firth of Clyde tourism case study, the evaluation of the secondary effects of sailing expenditure in the Firth was based on output multipliers. Key economic sectors that are mainly impacted by the recreational boating activities were identified representing relevant categories of spending, such as Recreational, cultural and sporting activities or Tourism (hotels, catering and pubs), Supporting and auxiliary transport activities, Retail. The direct effects were then multiplied up to derive the total economic effects of spending and thus capture the secondary economic effects of tourism activity. A similar approach is used in the analysis of Romanian Hotels and Restaurants Sector with respect to tourism [11].

An I/O matrix is a representation of national economic accounting that records the way industries trade with one another and produce (flows of products and services). Those flows are registered in a matrix, simultaneously by origin and by destination [8]. The matrix illustrates the relationship between producers and consumers as well as interdependencies of industries for a given year. The $\mathrm{I} / \mathrm{O}$ table is also called transactions matrix. The transactions matrix is divided into several sections. The section called the domestic intermediate matrix is a square matrix where the rows represent the outputs (suppliers) and the columns the destination of inputs (users). All the cells of the domestic intermediate matrix show the flows between sectors. Another section of the transactions matrix is called domestic investment matrix. It accounts for the supplies of goods that are not consumed by domestic industries. The rows represent sectors and the columns include such categories as Consumption expenditure, Gross Fixed Capital Formation, Changes in inventories, Direct purchases abroad by residents (imports), Direct purchases by non-residents (exports), Exports (cross border) and Imports (cross border). The columns in the third section of the transactions matrix correspond to the sectors with rows representing Taxes less subsidies on intermediate and final products, Total intermediate and final expenditure at purchasers' prices, Value added, Output, Labour compensation, Other value added, Taxes less subsidies on production, Consumption of fixed capital and Net operating surplus and mixed income. The initial monetary values in the domestic intermediate matrix can be converted into ratios by dividing each cell of the domestic intermediate matrix by its column total (output at basic prices). The square matrix obtained is called technical coefficients matrix (or the A matrix). The technical coefficients show the rate at which inputs are transformed into outputs. When the technical coefficients have been calculated, an identity matrix (or the I matrix) needs to be constructed. It is a square matrix with the same dimensions as the direct requirements matrix. The 
type I Leontief inverse matrix shows how much of each industry's output is needed, in terms of direct and indirect requirements to produce one unit of a given industry's output. Type I Leontief inverse matrix is calculated using the formula:

$$
L=(I-A)^{-1} \text {, }
$$

where

$L$ - Leontief Inverse matrix,

$I$ - Identity matrix,

$A$ - Direct Requirements matrix.

The type II Leontief inverse matrix shows the induced requirements (in terms of industry's output) of a production of one unit of a given industry's output. Its purpose is to take into account, besides the direct and indirect requirements included in the type I inverse matrix, the flows of money in and out of households and the effect of these flows on industries. The type II inverse matrix is derived in the same way as the type I inverse matrix. But since it is necessary to include households in the analysis we treat them as an additional industry by adding an extra row and column into the Direct Requirements matrix for "compensation of employees" and "final consumption expenditure by households" coefficients respectively. The formal notation for the Direct Requirements matrix is modified as follows:

$$
A=\left[\begin{array}{ll}
A_{I I} & A_{I H} \\
A_{H I} & A_{H H}
\end{array}\right],
$$

where

$\left(A_{I I}\right)_{i j}$ - square matrix representing the amount of industry $\mathrm{i}$ required per unit of industry $\mathrm{j}$ (Direct Requirements matrix in the type I inverse matrix),

$\left(A_{I H}\right)_{i}$ - vector representing the amount of industry i required per unit of total household income from all sources,

$\left(A_{H I}\right)_{j}$ - vector representing the income paid to households per unit of output of industry $i$ (compensation of employees divided by the total output of the industry),

$\left(A_{H H}\right)$ - single cell representing the household expenditure per unit of exogenous household income (this cell is set to zero value).

Previous research shows that the use of the "Total use at purchasers' prices" as the denominator when calculating household expenditure coefficients would tend to overestimate the induced effects of changes in the economy by artificially inflating the effect of earned income in generating further rounds of household spending as the sum of the household income vector components would equal 1. Not all household expenditure results from "Income from employment" paid to households as certain amount of household purchases is bought with unearned income (property income, inheritance, pensions and payments received from public welfare). A number of studies suggest the total household income provided by National Statistics offices should be used as the denominator when calculating household expenditure coefficients. The Type II Direct Requirements matrix is also called Augmented Direct Requirements matrix. There are seven types of multipliers and multiplier effects that can be calculated after the type I (or type II) inverse matrices have been derived: output, income, GVA and employment multipliers and income, GVA and employment multiplier effects. The multipliers and multiplier effects should be selected upon the purpose of the research and availability of input data for the calculations. For multipliers, the estimation of direct and indirect impacts on selected variable throughout the whole economy is generated by multiplying a change in final demand (direct impact) by Type I output multiplier. The estimation of direct, indirect and induced impacts on selected variable throughout the whole economy is generated by multiplying a change in final demand (direct impact) by Type II output multiplier. For effects, direct and indirect impacts are generated by using Type I Leontief inverse matrix, while using Type II Leontief inverse matrix also include induced effects in the economy. The research objectives suggest type I and type II income, GVA and employment multipliers should be derived.

\section{Income multiplier}

The Type I and II income multipliers for the industry sector $\mathrm{j}$ are calculated as follows:

$$
\left(I_{m u l t}\right)_{j}=\sum_{i} \frac{v_{i} L_{i j}}{v_{j}},
$$

where

$L$ - Leontief inverse matrix,

$v$ - vector representing the ratio of Income from Employment in the sector to total output of the sector. The Type I and II income multipliers show the increase in income from employment throughout the whole economy that results from a change of one currency unit $(€ 1)$ of income from employment in the industry sector $\mathrm{j}$.

GVA multiplier

The Type I and II GVA multipliers are calculated as follows:

$$
\left(G_{\text {mult }}\right)_{j}=\sum_{i} \frac{g_{i} L_{i j}}{g_{j}},
$$

where

$L$ - Leontief inverse matrix,

$g$ - vector referring to the ratio of GVA to total output for the sector.

The GVA multipliers show the increase in GVA throughout the whole economy that results from a change of one currency unit $(€ 1)$ of GVA in the industry sector $\mathrm{j}$.

\section{Employment multiplier}

The employment multiplier is calculated as follows:

$$
\left(E_{\text {mult }}\right)_{j}=\sum_{i} \frac{w_{i} L_{i j}}{w_{j}},
$$


where

$L$ - Leontief inverse matrix,

$w$ - vector referring to Full Time Employment (FTE) per one currency unit $(€ 1)$ of total output for the industry sector.

The employment multipliers show the total increases in employment throughout the whole economy which result from an increase in final demand which is enough to create one additional FTE in the industry sector $\mathrm{j}$.

Consistency testing the Leontief tables and multipliers

The consistency of the Leontief tables and multipliers is tested by calibration, matrix cell value comparison and ratio of income multipliers. The term "calibration" is used to describe the process whereby the Leontief Inverses are checked by calculating the matrix product of the Leontief and the vector of final demands. The outcome of this calculation (if the Leontief's are correct) is to recreate the base year gross outputs at basic prices. It should be apparent that, as the type II Leontief is equivalent to the type I Leontief but also includes induced (or household spending) effects, each and every cell in the type II matrix should be of equal or greater value to its type I equivalent. An extra check is carried out on the income multipliers. Dividing the type I income multiplier for each industry by the corresponding type II value should lead to a constant ratio across all industries.

The method has a few rather important shortcomings. I/O models assume that technological or economic relationships are fixed over time and do not respond to price or cost changes. The method does not reflect possible changes in regional productive structure as it always uses the same inputoutput table. In cases, it proves to be even more of a drawback if the available input-output table offers data corresponding to a year some way back in time.

\section{RESULTS AND DISCUSSION}

The data necessary for deriving the multipliers for Latvia were retrieved from the latest set of OECD harmonised national Input-Output Tables database which presents matrices of inter-industrial flows of goods and services either produced domestically or imported in current prices (USD million), covering the years 1995 to 2011 [9]. The OECD database of harmonised national tables takes the industry vs. industry approach covering all sectors of the economy. Considering the period of the policy intervention from 2007 to 2013 the study was based upon the 2009 tables.

As the period of the policy interventions analyzed begins in 2007, the use of I/O table for 2009 is justified by a commonly accepted 6 year period of stability of multipliers. Use of the latest $\mathrm{I} / \mathrm{O}$ table available for the year 2011 would cover only the ending of the interventions. However, the impact of the global financial crisis from 2008 on could not be reflected in the analysis. Thus, applying the proposed model, problems with timeliness of the key data raises questions regarding the validity of the results.

The standardized tables cover 34 industry sectors. As for the sector "Private households with employed persons" the corresponding rows and columns in the tables are set to zero values, only remaining 33 sectors are included in the matrices. First, the technical coefficients matrix is developed by dividing every cell in totals table to the corresponding sector's labour compensation. Then "I-A" matrix is calculated by subtracting technical coefficients matrix from an identity matrix with 33 rows and 33 columns. The type I Leontief inverse matrix is an inverse matrix of the "I-A" matrix. Second, the column of share of sector consumption expenditures in total consumption expenditures and the row of share of the labour compensation in total output are added to the totals table. The cell in the intersection of the $34^{\text {th }}$ row and $34^{\text {th }}$ column is set to zero. The total consumption expenditures for the Latvia in 2009 are provided by National Statistics office. Then "I-A" matrix is calculated by subtracting enlarged technical coefficients matrix from an identity matrix with 34 rows and 34 columns. The type II Leontief inverse matrix is an inverse matrix of the "I-A" matrix. Third, the vectors of coefficients are calculated. The vector $v$ is calculated by dividing labor compensation to industry output in every sector. The vector $g$ is calculated by dividing gross value added to industry output in every sector. The vector $w$ is calculated by dividing full time employment to industry output in every sector. Finally, the income, gross value added and employment Type I and Type II multipliers are calculated using formulae 3,4 and 5. After the calculation of the Type I and Type II multipliers, the consistency has been checked. Dividing the type I income multiplier for each industry by the corresponding type II value provides a constant ratio across all industries at 0.2364 . As preliminary research shows, this ratio for developed countries fluctuates around the value of 0.8 , e.g., 0.86 for The Netherlands in 2001. This points to a rather high share of unearned (possibly, undeclared and untaxed) income in Latvian household expenditures, thus making the use of the type II multipliers unreliable. The calculating of the matrix product of the Leontief and the vector of final demand is expected to recreate the base year gross outputs at basic prices. However, for some sectors the differences are rather marked. This can be explained by compiling the information on final demand variables from various sources. The final demand is calculated by extracting Imports (cross border) and Direct purchases abroad by residents (imports) from sum of Consumption expenditure, Gross Fixed Capital Formation, Direct purchases by non-residents (exports), Exports (cross border). This suggests the calculated values of multipliers should be treated cautiously. For research 
purposes, only industry sectors and multipliers with relevance to policy intervention should be considered. The overall objectives of the Latvian Rural Development Programme are focused on agriculture, forestry, food processing, rural tourism and local communities in terms of economic growth and employment creation. The indicators calculated previously for economic growth and employment creation are gross value added and full time employment, respectively. Thus, the corresponding industry sectors from I/O tables should be analyzed by using gross value added and employment multipliers. As for the economic growth, the previously estimated programme direct impacts are multiplied by respective gross value added multipliers to calculate the total secondary impact (Table 1). As some of the programme measures are targeted towards a number of sectors, the calculation of multipliers in that case is impossible. The multiplier value for these sectors is set to one assuming no secondary cumulative impact. Similarly, multiplier values are not applicable for the whole economy. The total estimated programme secondary cumulative impact on economic growth when accounting for multipliers exceeds the previously estimated direct impact more than three times. As all the multipliers are positive, the secondary respective impacts in all the sectors are positive, too. With respect to sectoral level, investments in food processing are the providing the most marked secondary cumulative impact on GVA, followed by agriculture and tourism (hotels and restaurants).

Table 1

Total secondary cumulative impact of the rural development Programme on economic growth (EUR million)

\begin{tabular}{|l|c|c|c|}
\hline \multicolumn{1}{|c|}{ Industry sector } & $\begin{array}{c}\text { Direct } \\
\text { impact }\end{array}$ & Multiplier & $\begin{array}{c}\text { Total } \\
\text { secondary } \\
\text { impact }\end{array}$ \\
\hline $\begin{array}{l}\text { Agriculture, hunting, } \\
\text { forestry\& fishing }\end{array}$ & 147.7 & 2.9091 & 428.3 \\
\hline $\begin{array}{l}\text { Food products, } \\
\text { beverages\& tobacco }\end{array}$ & 90.2 & 4.0954 & 369.8 \\
\hline Hotels and restaurants & 2.4 & 2.2948 & 5.5 \\
\hline $\begin{array}{l}\text { Other community, social } \\
\text { and personal services }\end{array}$ & 26.3 & 1.9643 & 52.6 \\
\hline Other sectors & 30.5 & 1.0000 & 30.5 \\
\hline Total & 297.1 & n.a & 886.8 \\
\hline
\end{tabular}

Table 2

Total secondary cumulative impact of the rural development programme on employment (AWU)

\begin{tabular}{|l|c|c|c|}
\hline \multicolumn{1}{|c|}{ Industry sector } & $\begin{array}{c}\text { Direct } \\
\text { impact }\end{array}$ & Multiplier & $\begin{array}{c}\text { Total } \\
\text { secondary } \\
\text { impact }\end{array}$ \\
\hline $\begin{array}{l}\text { Agriculture, hunting, } \\
\text { forestry\& fishing }\end{array}$ & -1197 & 1.9910 & -2383 \\
\hline $\begin{array}{l}\text { Food products, } \\
\text { beverages\& tobacco }\end{array}$ & 771 & 3.4451 & 2656 \\
\hline Hotels and restaurants & 82 & 1.4973 & 123 \\
\hline $\begin{array}{l}\text { Other community, social } \\
\text { and personal services }\end{array}$ & 82 & 1.0000 & 82 \\
\hline Other sectors & 1055 & 1.0000 & 1055 \\
\hline Total & 793 & n.a & 1533 \\
\hline
\end{tabular}

Similarly, the previously estimated programme direct impacts on employment are multiplied by respective employment multipliers to calculate the total secondary impact (Table 2).

The total estimated programme secondary cumulative impact on employment when accounting for multipliers exceeds the previously estimated direct impact almost two times. While the negative direct impact on employment in agriculture and forestry has almost doubled over the entire economy when multipliers are taken into account, the positive secondary cumulative impact in food processing more than offsets this.

\section{CONCLUSIONS}

The total estimated programme secondary cumulative impact on economic growth (Gross Value Added) exceeds the previously estimated direct impact more than three times.

With respect to sectoral level, investments in food processing are the providing the most marked secondary cumulative impact on GVA, followed by agriculture and tourism (hotels and restaurants). The total estimated programme secondary cumulative impact on employment (Annual Working Units) exceeds the previously estimated direct impact almost two times. With respect to sectoral level, investments in food processing are the providing the most marked secondary cumulative impact on AWU, followed by agriculture and tourism (hotels and restaurants). In general, policy interventions of Rural Development Programme provide significant positive secondary cumulative impact on economic growth and employment creation.

\section{V.ACKNOWLEDGEMENTS}

We thank our colleagues from other departments for assistance with Input - Output methodology, and for comments that greatly improved the manuscript.

\section{REFERENCES}

[1] EENRD, "Capturing the success of your RDP: Guidelines for the Ex post evaluation of 2007-2013 RDPs," June 2014.

[2] J. D'Hernoncourt, M. Cordier, and D. Hadley, "Input-Output Multipliers - Specification sheet and supporting material," in Spicosa Project Report, Université Libre de Bruxelles CEESE, Brussels, 2011.

[3] W. Leontief, The structure of American economy, 1919-1929: an empirical application of equilibrium analysis. Harvard University Press, 1941.

[4] W. Leontief, Studies in the Structure of the American Economy: Theoretical and Empirical Explorations in Inputoutput Analysis Harvard Economic Research Project. Oxford University Press, 1953.

[5] W. Leontief, Input-Output Economics. ${ }^{\text {nd }}$ ed., New York: Oxford University Press, 1986.

[6] P.J.A. Konijn, "The make and use of commodities by industries; on the compilation of input-output data from the national accounts," Faculty of Public Administration and Public Policy, University of Twente, Enschede, 1994.

[7] R.E. Miller and P.D. Blair, Input-Output Analysis: Foundations and Extensions. Prentice Hall, 1985.

[8] OECD, "Input - output analysis in an increasingly globalised world: applications of OECD's harmonized international 
tables," in STI/Working paper 2006/7. [Online]. Available: http://www.oecd.org/dataoecd/6/34/37349386.pdf. [Accessed January 12, 2017].

[9] OECD Input - Output Tables. [Online]. Available: http://www.oecd.org/trade/input-outputtables.htm. [Accessed January 12, 2017].

[10] J. Oosterhaven, Interregional input-output analysis and Dutch regional policy problems. Gower, 1981.
[11] D.J. Stynes, "Approaches to Estimating the Economic Impacts of Tourism: Some Examples," Michigan State University, 1999.

[12] C. Surugiu, "The economic impact of tourism. An inputoutput analysis," Romanian Journal of Economics 29 (2), pp. 142-161, 2009.

[13] M. Wilson, Sailing in the Clyde economic impact study, Scottish Enterprise Ayrshire, Glasgow, 2006. 